\title{
PENGEMBANGAN PENDIDIKAN ASWAJA SEBAGAI STRATEGI DERADIKALISASI
}

\author{
Ngainun Naim \\ Institut Agama Islam Negeri (IAIN) Tulungagung \\ e-mail: naimmas22@gmail.com
}

\begin{abstract}
This study discussed about the role of Aswaja lesson in the efforts of deradicalization. Radicalization had been more and more evolved since after the fall of New Order. Reformation Era opened wide varieties of expression, included religious expression. The development of radicalization led to widespread of social unrest. Responses appeared, included using the counter-ideology. Aswaja was believed as being able to prevent the proliferation of radicalization. The data presented in this article was derived from observation, interview and review of the literature related to the topic of writing. The argument developed in this paper is that the reconstruction and actualization of the values contained in Aswaja might be personally internalized firmly. An important strategy that might be applyed to disseminate and internalize Aswaja is through education. In the schools in which applying Aswaja lesson, students had the opportunity to have a moderate religious understanding and avoid radicalization.
\end{abstract}

Penelitian ini mengulas tentang peranan pelajaran Aswaja dalam usaha deradikalisasi. Radikalisasi semakin berkembang pasca jatuhnya Orde Baru. Era Reformasi membuka lebar berbagai bentuk ekspresi, termasuk ekspresi keberagamaan. Semakin berkembangnya radikalisasi memunculkan keresahan masyarakat secara luas. Berbagai respons pun muncul, di antaranya melalui counterideologi. Aswaja diyakini dapat mencegah tumbuh suburnya radikalisasi. Data yang disajikan dalam artikel ini berasal dari observasi, wawancara dan telaah literatur yang berkaitan dengan topik tulisan. Argumen yang dibangun dalam tulisan ini adalah rekonstruksi dan aktualisasi nilai-nilai yang terkandung di dalam Aswaja dapat terinternalisasi secara kokoh dalam diri seseorang. Strategi penting yang dapat ditempuh untuk sosialisasi dan internalisasi Aswaja adalah melalui jalur pendidikan. Di sekolah-sekolah yang mengaplikasi mata pelajaran Aswaja, para siswanya memiliki peluang untuk memiliki pemahaman keagamaan yang moderat dan terhindar dari arus radikalisasi.

Keywords: radikalisasi, deradikalisasi, Aswaja, sosialisasi, internalisasi 


\section{A. Pendahuluan}

Radikalisme merupakan fenomena yang semakin marak di Indonesia dalam beberapa tahun akhir. Hal ini ditandai -antara lain- dengan lahirnya organisasi-organisasi keagamaan yang sering menggunakan cara-cara kekerasan dalam menjalankan misinya. Organisasi Islam radikal memiliki karakteristik, varian dan orientasi yang bermacam-macam. Namun demikian, ada kesamaan di antara organisasi-organisasi Islam radikal, yaitu penggunaan jalan kekerasan.

Pertumbuhan secara masif gerakan Islam radikal mendapatkan respons yang beragam dari berbagai pihak. Ada yang memberikan respons positif dengan mendukung, ada yang memberi respons reaktif-emosional, ada yang memberikan respons kreatif, dan ada juga yang merespon secara anarkis. Sejauh ini, respons yang diberikan belum membendung -apalagi menghentikan- laju pertumbuhan gerakan Islam radikal. Justru ada kecenderungan terjadi peningkatan jumlah anggota pada berbagai organisasi Islam radikal.

Eksistensi organisasi Islam radikal sesungguhnya merupakan ancaman bagi masa depan Islam Indonesia. Islam Indonesia merupakan Islam yang dikenal dengan karakter ramah, toleran dan humanis. Dinamika dan pertumbuhan Islam di Indonesia selama ratusan tahun menunjukkan bahwa Islam toleran dan damai dapat hidup menyatu dengan masyarakat Indonesia. Islam radikal sesungguhnya merupakan karakteristik Islam yang tidak memiliki harapan hidup di masa depan. Hal ini disebabkan oleh -salah satunya- penafian yang dilakukan oleh kelompok Islam radikal terhadap kearifan nilai-nilai kultur Indonesia. ${ }^{1}$ Karena tidak menghargai terhadap nilai-nilai kultur Indonesia maka Islam radikal sering menggunakan cara-cara yang bertentangan dengan realitas budaya yang telah mengakar kuat di masyarakat. Tidak jarang kelompok Islam radikal menggunakan jalan kekerasan dalam melaksanakan aktivitasnya. Jalan kekerasan yang mereka tempuh akan memicu timbulnya kekerasan demi kekerasan berikutnya. Jika Islam radikal terus mengembangkan sayap ke berbagai bidang kehidupan maka kehidupan damai dan toleran akan semakin sulit untuk kita temukan.

\footnotetext{
1Wasid Mansyur, Menegaskan Islam Indonesia, Belajar dari Tradisi Pesantren dan NU, (Surabaya: Pustaka Idea, 2014), h. 41.
} 
Dalam kerangka inilah organisasi Islam arus utama (mainstream) merasakan perlu untuk memberikan respons aktif-kreatif-konstruktif agar organisasi Islam radikal tidak semakin menancapkan akar pengaruhnya. Infiltrasi gerakan Islam radikal dilakukan secara masif, khususnya terhadap generasi muda. Pilihan terhadap generasi muda ini cukup strategis, karena generasi muda pada umumnya belum memiliki pengalaman matang dalam persoalan keagamaan. Mereka mudah untuk didoktrin dengan ideologi tertentu. Generasi muda yang direkrut ke dalam kelompok Islam radikal biasanya sangat ideologis dan siap berjuang dengan kompensasi apa pun demi menjalankan visi dan misi organisasinya.

Semakin banyaknya generasi muda yang masuk ke dalam organisasi Islam radikal tampaknya menyadarkan banyak pihak untuk segera menguatkan benteng pertahanan. Jika tidak diantisipasi maka benih-benih radikalisme akan tersemai dan berkembang secara luas. Semakin meluasnya Islam radikal berimplikasi pada semakin kecilnya peluang membangun harmoni sosial dalam masyarakat Indonesia yang multikultur. Jalan kekerasan dan intoleransi akan semakin meluas karena karakteristik Islam radikal memang semacam itu.

Salah satu upaya yang penting untuk mencegah berkembangnya Islam radikal adalah melalui pelajaran tertentu. Pelajaran yang disampaikan di kelas adalah media terstruktur dan sistematis yang memungkinkan siswa mengetahui dan memahami sebuah persoalan secara lebih baik. Melalui sebuah pelajaran, siswa bisa memahami apa itu Islam radikal, karakteristiknya, bahayanya, dan berbagai aspeknya secara komprehensif. Salah satu pelajaran yang dapat mencegah radikalisasi adalah pelajaran Aswaja.

Pelajaran Aswaja merupakan salah satu pelajaran wajib di SMA Diponegoro Tulungagung. Sekolah ini berada di bawah naungan Lembaga Pendidikan Ma'arif Nahdlatul Ulama (LP Ma'arif NU) Tulungagung. Pelajaran Aswaja (Ahl al-Sunnah wa '-Jamā'ah) memiliki potensi yang besar untuk menjadi counter atas semakin menguatnya arus Islam radikal. Hal ini disebabkan karena Aswaja merupakan sistem teologi yang moderat. Ajaran Aswaja dapat dijadikan sebagai sarana membangun pemahaman Islam yang toleran, inklusif dan moderat. Selain itu, Aswaja yang tertanam sebagai pengetahuan, pemahaman dan sikap merupakan modal penting untuk bersikap kritis dalam menghadapi dinamika sosial keagamaan yang semakin kompleks. Berkaitan dengan itulah maka tulisan ini akan membahas tiga hal, yaitu: (1) nilai-nilai dasar yang terdapat dalam Aswaja; (2) signifi- 
kansi Aswaja dalam konteks sekarang ini; dan (3) strategi internalisasi Aswaja di SMA Diponegoro Tulungagung.

\section{B. Deradikalisasi Berbasis Pendidikan}

Islam radikal secara umum dianggap sebagai ancaman. Jalan kekerasan yang mereka gunakan, baik dalam bentuk kekerasan sistemik, kekerasan aktual, atau kekerasan simbolik, menjadikan kehadiran Islam radikal sebagai teror mental yang mencekam bagi kelompok Islam yang lain. Karakter yang melekat pada kelompok Islam radikal adalah meyakini bahwa pemahaman keagamaan yang mereka usung merupakan kebenaran mutlak. Implikasi dari keyakinan semacam ini adalah tidak adanya ruang dialog konstruktif untuk mendiskusikan berbagai persoalan dalam kehidupan.

Berkembangnya Islam radikal, di Indonesia sesungguhnya menjadi tantangan besar bagi kehidupan umat beragama. Indonesia merupakan negara yang memiliki karakteristik plural. Bahkan Indonesia merupakan negara yang masyarakatnya paling plural. ${ }^{2}$ Karena itu bukan suatu penilaian berlebihan jika dinyatakan bahwa Indonesia merupakan negara yang multi-etnis, multi-iman, dan multi-ekspresi kultural politik. Karena itulah, sebagaimana ditegaskan Ma'arif, keanekaragaman yang dimiliki oleh Indonesia ini harus dikelola secara baik, cerdas, dan jujur. Jika pengelolaannya mampu dilaksanakan secara optimal maka dapat berubah menjadi kekayaan kultural yang dahsyat. ${ }^{3}$

Kekayaan kultural yang sedemikian dahsyat bisa hancur di tangan kelompok Islam radikal. Islam radikal tidak mau menerima adanya kebenaran dari luar kelompok mereka. Gagasan yang mereka usung tidak untuk didiskusikan atau diperdebatkan, melainkan untuk diterima secara mutlak. Jika ada orang atau kelompok yang tidak mau menerima, mereka akan menggunakan berbagai cara agar bisa diterima. Tidak jarang mereka menggunakan istilah yang menyesatkan untuk menuduh kelompok lain. Kafir merupakan istilah yang begitu mudah mereka sematkan. Padahal, mereka yang kafir itu, "wajib diperangi sampai titik darah penghabisan". ${ }^{4} \mathrm{Hal}$ ini bermakna Islam radikal

\footnotetext{
2Abdul 'Dubbun' Hakim, "Islam, Inklusivisme, dan Kosmopolitanisme," dalam Abdul Halim (ed.), Menembus Batas Tradisi Menuju Masa Depan yang Membebaskan, Refleksi atas Pemikiran Nurcholish Madjid, (Jakarta: Kompas dan Universitas Paramadina, 2006), h. 19.

${ }^{3}$ Ahmad Syafi'i Ma'arif, Islam dalam Bingkai Keindonesiaan dan Kemanusiaan: Sebuah Refleksi Sejarah, (Bandung: Mizan bekerja sama dengan Ma’arif Institute Jakarta, 2009), h. 246.

4Zuly Qodir, Radikalisme Agama di Indonesia, (Yogyakarta: Pustaka Pelajar, 2014), h. 41.
} 
mengabsahkan penggunaan jalan apa pun, termasuk jalan kekerasan, terhadap mereka yang tidak setuju dengan pendapat mereka.

Realitas keanekaragaman yang dimiliki oleh bangsa Indonesia dapat berubah menjadi petaka ketika berhadapan dengan ideologi Islam radikal. Pandangan dunia Islam radikal tidak bisa menerima realitas keanekaragaman. Realitas ideal yang dikembangkan adalah realitas tunggal sesuai dengan konsepsi mereka. Mereka tidak menerima adanya perspektif yang berbeda. Jika melihat sesuatu yang berbeda maka harus diubah agar sejalan dengan perspektif mereka.

Dalam kerangka mewujudkan hal tersebut, kelompok Islam radikal menempuh berbagai cara, termasuk dengan jalan kekerasan. Jika ini yang terjadi maka kekayaan kultural yang dimiliki oleh Indonesia akan tercabik-cabik. Berbagai kelompok multi yang ada bisa terjatuh dalam kondisi yang saling serang. Sebab tidak mungkin memaksakan cara pandang tunggal dalam berbagai bidang kehidupan karena realitas sendiri sesungguhnya memang tidak tunggal.

Kehadiran kelompok Islam radikal, selain sebagai tantangan besar, sesungguhnya juga berhadapan dengan utopia. Visi utama kelompok Islam radikal adalah memurnikan ajaran Islam. Menurut Kato, "pemurnian agama sebagaimana dilakukan kaum radikal merupakan khayalan belaka". ${ }^{5}$ Hal ini disebabkan karena pemurnian sebagaimana yang mereka klaim sesungguhnya merupakan interpretasi. Sebagai hasil interpretasi, pemahaman keagamaan yang dihasilkannya bersifat relatif. Pemahaman tersebut tidak bisa diklaim sebagai yang paling benar. Hasil interpretasi, termasuk yang diklaim sebagai pemurnian, pada dasarnya dipengaruhi oleh berbagai faktor, baik faktor budaya, sosial, politik, dan pendidikan. Justru karena itulah maka klaim yang mengatasnamakan sebagai paling murni atau paling benar tidak bisa diterima.

Salah satu media yang cukup efektif untuk membendung arus Islam radikal adalah pendidikan. Menurut Nik Hassan, kemajuan yang bisa dicapai oleh manusia itu sifatnya tidak parsial, melainkan komprehensif. Titik pijak kemajuan tersebut adalah adanya kepedulian yang tinggi terhadap dunia pendidikan. Pendidikan menjadi media penting untuk mengantarkan seseorang memiliki karakter yang baik. Melalui pendidikan, seseorang akan mendapatkan pengeh. 101.

${ }^{5}$ Hisanori Kato, Kangen Indonesia, Indonesia di Mata Orang Jepang, cet. III, (Jakarta: Kompas, 2013), 
tahuan dan keahlian yang tinggi. Semua itu mungkin untuk diperoleh malalui kemampuan intelektual. Pada saat yang sama, pengetahuan dan kemampuan yang dimiliki tersebut juga selaras dengan kebutuhan bangsa. ${ }^{6}$

Melalui pendidikan, seseorang bisa mendapatkan wawasan, pengalaman, pengetahuan, dan keterampilan hidup yang memadai. Apa yang diperoleh dari dunia pendidikan dapat menjadi modal penting dalam menjalani kehidupan. Lebih dari itu, pendidikan sesungguhnya merupakan tabungan kekayaan di masa depan, baik kekayaan berupa finansial, intelektual, sosial, maupun kultural. ${ }^{7}$ Modal ini tidak bisa diperoleh oleh setiap orang yang menempuh jenjang pendidikan. Hanya mereka yang serius dan tekun menjalani proses pembelajaran dan mengembangkan potensi diri secara optimal saja yang bisa memperoleh manfaat pendidikan secara luas.

Keberhasilan mewujudkan tujuan tersebut tidak hanya ditentukan oleh faktor anak didik semata. Ada banyak faktor lain yang saling berkaitan. Secara substansial, proses pendidikan dipengaruhi oleh sistem pendidikan secara keseluruhan. Berangkat dari pemahaman tentang signifikansi pendidikan tersebut maka pendidikan perlu dikonsentrasikan untuk menghasilkan anak didik yang memiliki kemampuan andal. Kemampuan ini bisa diperoleh melalui usaha-usaha pemberdayaan sumber daya manusia secara maksimal. Usaha maksimal ini diharapkan mampu melahirkan manusia yang terpelajar dan berbudaya (educated and civilized human being) yang dapat mengangkat kehormatan atau martabatnya. ${ }^{8}$

Signifikansi pendidikan ini sesungguhnya juga menjadi kesadaran hampir semua tokoh penting dunia. Salah satunya adalah tokoh besar India, Sayyid Ahmad Khan. Begitu pentingnya makna pendidikan sampai beliau mengatakan, "Didiklah, didiklah, didiklah! Semua penyakit sosial politik di India bisa diobati dengan cara ini. Obatilah akarnya dan pohonnya akan subur". ${ }^{9}$ Kalimat Ahmad Khan tersebut menunjukkan betapa pentingnya pendidikan. Memang, pendidikan diyakini sebagai sarana yang penting untuk mengatasi berbagai per-

\footnotetext{
${ }^{6}$ Nik Mustapha Hj. Nik Hassan, "Civil Society for Sustainable Economic Development," dalam Syed Othman Alhabshi and Nik Mustapha Nik Hassan (eds.), Islam Knowledge and Ethics: a Partinent Culture for Managing Organizations, (Kuala Lumpur: Institute of Islamic Understanding Malaysia (IKIM), 1998), h. 184.

${ }^{7}$ Mujamil Qomar, Menggagas Pendidikan Islam, (Bandung: Remaja Rosdakarya, 2014), h. 128.

8Mujamil Qomar, Menggagas Pendidikan Islam, h. 130.

${ }^{9}$ A. Mukti Ali, Alam Pikiran Islam Modern di India dan Pakistan, (Bandung: Mizan, 1993), h. 65-66.
} 
soalan dalam kehidupan. Pendidikan yang bermutu menjadi modal penting untuk mengatasi berbagai persoalan yang ada. Manusia-manusia bermutu yang dihasilkan oleh dunia pendidikan dapat memberikan kontribusi, baik teori, strategi maupun kontribusi yang lainnya, untuk menyelesaikan berbagai permasalahan yang tengah berkembang. Tidak hanya itu, manusia-manusia yang terdidik memiliki peluang yang lebih besar untuk membantu membangun kemajuan kehidupan dalam skala luas.

Berangkat dari pemikiran yang semacam inilah maka dibutuhkan upaya sistematis melalui jalur pendidikan untuk mencegah tumbuh dan berkembangnya radikalisme. Realitas semakin suburnya radikalisme membutuhkan penanganan serius yang melibatkan seluruh komponen bangsa. Berbagai pihak, mulai negara, agamawan hingga masyarakat harus melakukan langkahlangkah nyata agar radikalisme dapat dieliminir keberadaannya.

\section{Nilai-nilai Aswaja}

Di tengah arus radikalisme yang semakin menguat, nilai-nilai yang terkandung di dalam Aswaja menjadi signifikan untuk dimunculkan dan diaktualisasikan. Nilai-nilai Aswaja dapat dijadikan sebagai counter untuk membendung arus radikalisme. Melalui rekonstruksi nilai-nilai Aswaja yang kemudian disosialisasikan secara masif -salah satunya melalui jalur pendidikan- diharapkan dapat memberikan pemahaman masyarakat terhadap signifikansi ajaran Islam yang moderat.

Islam sesungguhnya tidak identik dengan kekerasan. Cara-cara damai yang membuat Islam bisa hadir dan menjadi bagian tidak terpisah dari kehidupan Indonesia selama ratusan tahun. Karena itulah ajaran Aswaja tidak setuju dengan ajaran-ajaran akidah yang dimiliki oleh kelompok-kelompok Islam radikal. Aswaja tidak setuju dengan respons dan penyelesaian persoalan melalui jalan kekerasan, pemaksaan, apalagi dengan perusakan. Aswaja juga menolak terhadap eksistensi kelompok-kelompok yang menutup diri dari golongan mayoritas kaum Muslimin. ${ }^{10}$ Pengalaman sejarah Islam Indonesia yang mengedepankan interaksi sosial yang harmonis penting untuk diperhatikan agar masa depan Islam Indonesia tidak terpuruk dalam konflik.

\footnotetext{
${ }^{10}$ Masyhudi Muchtar, dkk., Aswaja An-Nahdliyah, Ajaran Ahlussunnah wa al-Jama'ah yang Berlaku di Lingkungan Nahdlatul Ulama, (Surabaya: Khalista dan LTN NU Jawa Timur, 2007), h. 18.
} 
Rekonstruksi Aswaja menjadi penting dilakukan karena tuntutan transformasi kehidupan yang semakin cepat. Tanpa melakukan rekonstruksi dikhawatirkan Aswaja akan kehilangan relevansi dan aktualitas. Lebih jauh, umat Islam -khususnya generasi muda- tidak lagi mengenal ajaran Islam moderat sebagaimana yang diusung Aswaja. Tidak tertutup kemungkinan mereka justru menjadi pengikut dan aktivis gerakan Islam radikal.

Paradigma pemikiran Aswaja bertumpu pada sumber ajaran Islam; alQur'an, al-Sunnah, al-Ijmā', dan Qiyās. Sementara pada tataran praktik, umat Islam yang menganut Aswaja mengikuti produk pemikiran ulama di masa lalu. Ada tiga pilar inti yang menandai karakteristik Aswaja, yaitu mengikuti paham al-Asy'ari dan al-Maturidi dalam bidang teologi, mengikuti salah satu dari empat imam mazhab (Hanafi, Maliki, Syafi'i, dan Hanbali) dalam bidang Fiqih, dan mengikuti Imam Junaid al-Baghdadi dan Imam al-Ghazali dalam bidang tasawuf. ${ }^{11}$

Selain tiga pilar inti, Aswaja juga memiliki nilai-nilai yang menarik. Nilainilai tersebut yang pertama adalah tawassut (moderat). Menurut Kamus Besar Bahasa Indonesia, moderat memiliki dua arti, yaitu: (1) selalu menghindarkan perilaku atau pengungkapan yang ekstrem; (2) berkecenderungan ke arah dimensi atau jalan tengah. ${ }^{12}$ Pemikiran moderat penting artinya karena dapat direkonstruksi untuk menjadi spirit perdamaian. Moderat menjadi modal penting untuk mengakomodasi berbagai kepentingan yang ada dan mencari solusi terbaik atas pertentangan yang terjadi.

Kedua, tawāzun (berimbang). Berimbang yang dimaksudkan dalam konteks ini adalah sikap berimbang dan harmonis dalam mengintegrasikan dan mensinergikan dalil-dalil untuk menghasilkan sebuah keputusan yang bijak. Tawāzun (berimbang) ini merupakan manifestasi dari sikap keberagamaan yang menghindari sikap ekstrem. Kelompok radikal disebut sebagai kelompok ekstrem karena kurang menghargai terhadap perbedaan pendapat dan tidak mengakomodasi kekayaan khazanah kehidupan.

Ketiga, toleransi (tasāmuḥ) yang sangat besar terhadap pluralisme pikiran. Berbagai pikiran yang tumbuh dalam masyarakat Muslim mendapatkan 80-85.

11M. Masyhur Amin, NU dan Ijtihad Politik Kenegaraannya, (Yogyakarta: Al-Amin Press, 1996), h.

12Departemen Pendidikan dan Kebudayaan, Kamus Besar Bahasa Indonesia, cet. III, (Jakarta: Balai Pustaka, 1990), h. 589. 
pengakuan yang apresiatif. Keterbukaan yang demikian lebar untuk menerima berbagai pendapat menjadikan Aswaja memiliki kemampuan untuk meredam berbagai konflik internal umat Islam. Corak ini sangat tampak dalam wacana pemikiran hukum Islam. Wacana hukum Islam oleh banyak ahli dinilai sebagai wacana pemikiran keislaman yang paling realistik dan paling banyak menyentuh aspek relasi sosial. Dalam diskursus sosial budaya, Aswaja banyak melakukan toleransi terhadap tradisi-tradisi yang telah berkembang di masyarakat, tanpa melibatkan diri dalam substansinya, bahkan tetap berusaha untuk mengarahkannya. Formalisme dalam aspek-aspek kebudayaan dalam Aswaja tidaklah memiliki signifikansi yang kuat. Sikap toleran Aswaja telah memberikan makna khusus dalam hubungannya dengan dimensi kemanusiaan yang luas. ${ }^{13}$

Dengan nilai-nilai tersebut, Islam menjadi agama yang mampu berdialektika secara dinamis dengan budaya lokal. SMA Diponegoro Tulungagung sebagai lembaga pendidikan yang berada di bawah naungan LP Ma'arif NU Tulungagung, ${ }^{14}$ juga mengembangkan pembelajaran yang materinya sejalan dengan nilai-nilai Aswaja. Pilihan strategi yang akomodatif terhadap budaya lokal ini juga dikembangkan oleh banyak tokoh NU. Salah satunya adalah KH. Achmad Siddiq. Menurut Kiai Achmad Siddiq, agama Islam itu berwatak fitri. Maksud dari watak fitri ini adalah sesuai dengan hati nurani, kemampuan dan kebutuhan manusia. Karena fitri maka ia belum dipengaruhi oleh hawa nafsu. Agama Islam ini datang tidak untuk menghapuskan segala yang sudah ada dan menolak segala hal yang datang dari luar. Berbagai aspek dalam kehidupan yang sesuai dengan ajaran Islam diteruskan dan dikembangkan, sedangkan yang bertentangan dilarang atau dihapus. ${ }^{15}$

Sikap akomodatif terhadap tradisi lokal tidak hanya menjadi monopoli pemikiran kiai NU. Intelektual yang bukan NU -salah satunya Nurcholish Madjidjuga mengapresiasi terhadap budaya lokal. Menurut Nurcholish Madjid, kedatangan Islam selalu berimplikasi pada terjadinya transformasi sosial menuju kehidupan yang lebih baik. Namun pada saat yang sama, kedatangan Islam tidak

\footnotetext{
${ }^{13}$ Husein Muhammad, "Memahami Sejarah Ahlus Sunnah wal-Jama'ah yang Toleran dan Anti Ekstrem," dalam Imam Baehaqi (ed.), Kontroversi Aswaja, Aula Perdebatan dan Reinterpretasi, (Yogyakarta: LKiS, 2000), h. 37-41. 2015.

${ }^{14}$ Wawancara dengan Muhtarom, Kepala SMA Diponegoro dan guru Aswaja, Selasa, 27 Januari

${ }^{15}$ Lukman Hakim, Perlawanan Islam Kultural: Relasi Asosiatif Pertumbuhan Civil Society dan Doktrin Aswaja NU, (Surabaya: Pustaka Eureka, 2004), h. 104.
} 
mesti 'disruptif atau bersifat memotong suatu masyarakat dari masa lampaunya, tetapi juga ikut melestarikan aspek yang baik dari masa lampau tersebut dan bisa dipertahankan ujian ajaran universal Islam. ${ }^{16}$

Islam Indonesia dalam sejarahnya memiliki relasi yang cukup baik dengan tradisi lokal. Interaksi dinamis antara Islam dan tradisi lokal membentuk Islam yang khas. Interaksi semacam ini terus tumbuh dan berkembang sehingga perlu untuk dijaga, dikelola dan dijadikan bagian tidak terpisah dari kehidupan Islam Indonesia.

\section{Signifikansi Rekonstruksi Aswaja}

Secara sosiologis setiap orang memiliki peluang untuk mengalami transformasi diri. Tidak tertutup kemungkinan untuk terjadi perubahan pada diri seseorang yang pada awalnya baik dan santun namun dalam perkembangannya kemudian berubah menjadi seorang aktivis aliran radikal. Aktivitasnya itu berimplikasi pada ketakutan masyarakat pada skala luas. Transformasi ini terjadi karena berbagai faktor., yang salah satunya adalah karena interaksinya dengan kelompok Islam radikal.

Generasi muda menjadi sasaran karena -salah satunya- kondisi psikologis mereka yang belum stabil. Mereka mudah goyah kondisi psikologisnya saat berhadapan dengan dinamika kehidupan yang terus berubah. Berbagai hal yang baru juga selalu menarik bagi generasi muda. Dengan kondisi psikologis yang semacam itu para aktivis Islam radikal masuk dan menanamkan pengaruhnya. Karena itulah sebagian besar pengikut dan sasaran rekrutmen gerakan Islam radikal adalah kalangan generasi muda.

Para aktivis Islam radikal melakukan kegiatan rekrutmen anggota baru secara intensif. Sekolah dan kampus menjadi wilayah prioritas. Mereka berusaha masuk ke berbagai sekolah dan kampus melalui berbagai cara. Salah satunya adalah dengan datang menawarkan diri untuk berbagai bentuk kegiatan. ${ }^{17}$ Kelompok radikal memang memiliki ikatan ideologis yang sangat kuat dengan ajaran agama yang diyakininya. Mereka tidak mudah patah semangat. Berbagai penolakan -secara halus atau kasar- tidak membuat mereka mudah

\footnotetext{
${ }^{16}$ Nurcholish Madjid, Islam, Doktrin dan Peradaban, (Jakarta: Paramadina, 1992), h. 552.

17Wawancara dengan Muhtarom, Selasa, 27 Januari 2015.
} 
menyerah. Bagi mereka, sosialisasi ajaran dan merekrut anggota baru adalah bagian dari jihad.

Gencarnya arus Islam radikal dan semakin banyaknya generasi muda yang masuk ke dalam kelompok semacam ini merupakan tantangan yang harus dijawab secara aktif-kreatif. Sebab jika dibiarkan maka kelompok Islam radikal akan semakin intensif menebarkan jejaknya. Mereka akan semakin bersemangat merekrut anggota baru. Jika ini dibiarkan maka masa depan Islam Indonesia akan suram.

Pada kerangka inilah diperlukan berbagai pemikiran untuk merespon masifnya gerakan Islam radikal. Rekonstruksi Aswaja untuk kemudian disosialisasikan secara sistematis merupakan salah satu langkah yang penting untuk dipertimbangkan. Aswaja bukan ajaran normatif yang tidak operasional. Justru pada kondisi sekarang inilah rekonstruksi Aswaja agar mampu menjadi bagian tidak terpisah dari perilaku hidup sehari-hari menjadi penting untuk dilakukan.

Signifikansi rekonstruksi Aswaja juga disebabkan oleh beberapa alasan. Pertama, Aswaja menjadi identitas teologis yang diperebutkan oleh berbagai aliran maupun organisasi Islam. Tidak sedikit aliran atau organisasi yang mengklaim dirinya sebagai Aswaja. Justru karena menjadi ajang perebutan klaim inilah maka rekonstruksi menjadi penting dilakukan. Persoalannya bukan siapa yang paling benar dan paling berhak disebut sebagai penganut Aswaja, tetapi mana yang dapat menjadikan nilai-nilai Aswaja sebagai basis untuk menjalankan aktivitas sehari-hari dalam berbagai bidang kehidupan. Klaim tidak banyak maknanya jika sebatas klaim tanpa diikuti dengan aktivitas yang mendukung klaim tersebut.

Kedua, substansi Aswaja masih menjadi ruang perdebatan yang hingga sekarang pun belum tuntas. Hal ini disebabkan karena memang definisi, ruang lingkup, dan karakteristik Aswaja memang longgar. Namun demikian ada titik pijak umum yang menandai karakteristik Aswaja. Aspek inilah yang seharusnya dikemukakan, bukan justru titik bedanya yang dibesar-besarkan untuk kemudian menjadi ajang perdebatan yang tidak berujung.

Ketiga, Aswaja belum tersosialisasi dan tersusun secara sistematis dalam berbagai bidang kehidupan. Aswaja yang dianut oleh umat Islam Indonesia khususnya warga Nahdlatul Ulama- sifatnya masih elitis di kalangan kaum terdidik. Warga masyarakat umum biasanya kurang tahu dan kurang peduli terhadap Aswaja. Justru karena hal inilah maka rekonstruksi Aswaja menemukan signifikansinya. 
Rekonstruksi Aswaja dapat dimulai dari hal-hal kecil dan sederhana tetapi memiliki pengaruh yang luas dan mendalam. Di SMA Diponegoro Tulungagung, Aswaja menjadi pelajaran wajib bagi seluruh siswa selama mereka sekolah. Selama tiga tahun mereka terus-menerus mendapatkan pelajaran tentang Aswaja. Pemberian pelajaran Aswaja yang dilakukan secara sistematis merupakan wahana mendasar untuk menguatkan Aswaja sebagai bagian tidak terpisah dari kehidupan sehari-hari.

Strategi semacam ini cukup strategis karena untuk menjadikan Aswaja sebagai way of life dipengaruhi oleh beberapa faktor. pertama, pandangan teologi agama dan doktrin ajarannya. Kedua, sikap dan perilaku pemeluk agama dalam memahami dan menghayati terhadap ajaran agamanya. Ketiga, realitas lingkungan sosial budaya yang berada di sekeliling. Keempat, peranan dan pengaruh pemuka agama, termasuk juga pengaruh guru agama, dalam mengarahkan pengikut atau para muridnya. ${ }^{18}$

Ada tiga hal yang mendasar untuk diajarkan, yakni: pengertian Aswaja, materi Aswaja dan implementasinya. Pengertian Aswaja penting untuk dijelaskan secara runtut, sistematis, dan sesuai dengan penalaran para siswa. "Penjelasannya harus sederhana dan diulang-ulang. Mungkin agak membosankan tetapi cara semacam ini cukup efektif untuk membangun pengertian para siswa," tegas Muhtarom. ${ }^{19}$

Selain pengertian Aswaja, materi yang juga penting untuk diajarkan adalah implementasi Aswaja dalam berbagai bidang kehidupan. Materi penting karena mengejawantahkan tataran konsep ke tataran praktis. Guru Aswaja menjelaskan secara detail materi ini, yaitu implementasi Aswaja dalam bidang akidah, syariah, akhlak, kemasyarakatan, sosial, politik, budaya, dan berbagai bidang yang lainnya. melalui penjelasan semacam ini diharapkan para siswa semakin paham dan mengetahui karakteristik Aswaja pada level praktis.

"Mengajarkan Aswaja itu yang penting doktrin", tegas Muhtarom..$^{20}$ Doktrin yang diajarkan secara berulang-ulang diharapkan dapat menjadi bagian dari pemahaman dan perilaku hidup sehari-hari. Dalam kerangka jangka panjang,

\footnotetext{
${ }^{18}$ Muhaimin, "Urgensi Pendidikan Islam Multikultural untuk Menciptakan Toleransi dan Perdamaian di Indonesia," dalam Ali Maksum, Pluralisme dan Multikulturalisme Paradigma Baru Pendidikan Agama Islam di Indonesia, (Yogyakarta: Aditya Media, 2011), h. xvi. 2015.

${ }^{19}$ Wawancara dengan Muhtarom, Kepala SMA Diponegoro dan guru Aswaja, Selasa, 27 Januari

${ }^{20}$ Wawancara dengan Muhtarom, Selasa, 27 Januari 2015.
} 
doktrin yang telah tertanam diharapkan menjadi modal penting dalam menjalani kehidupan dan saat berinteraksi dengan berbagai aliran yang ada.

\section{E. Strategi Internalisasi Aswaja}

Di SMA Diponegoro Tulungagung ini, Aswaja diajarkan sejak kelas X sampai kelas XII. Selama tiga tahun, seluruh siswa mendapatkan pelajaran Aswaja secara simultan. Pelajaran Aswaja yang diberikan selama para siswa duduk di bangku SMA Diponegoro ini dilakukan dalam kerangka memberikan pemahaman dan internalisasi nilai secara subtil ke dalam diri setiap siswa.

Kurikulum Aswaja yang diajarkan selama tiga tahun didesain dengan tujuan memberikan pemahaman kepada para siswa tentang Aswaja. Secara substansial, pembalajaran ini dilakukan dalam kerangka penanaman Aswaja sebagai doktrin. Penjelasan dalam pembelajaran dilakukan dalam kerangka internalisasi terhadap kebenaran yang terdapat dalam ajaran Aswaja.

Proses pembelajaran semacam ini memberi kesempatan kepada para siswa untuk mengenal, mengetahui, dan memahami tentang Aswaja dari berbagai aspeknya. Usaha pembelajaran semacam ini dalam realitasnya cukup efektif dalam membentengi diri para siswa dari pengaruh paham Islam radikal. Hal ini bisa dicermati dari realitas tidak adanya siswa yang menganut paham Islam radikal.

Pengaruh pembelajaran Aswaja tidak hanya saat siswa masih duduk di bangku sekolah. Modal yang mereka peroleh saat sekolah ternyata sangat berguna saat para siswa melanjutkan studinya ke perguruan tinggi. Tidak sedikit lulusan SMA Diponegoro yang melanjutkan studi ke berbagai perguruan tinggi di berbagai kota besar. Kota besar merupakan tempat persemaian yang subur bagi lahirnya gerakan Islam radikal.

Kemunculan Islam radikal sesungguhnya berkelindan dengan berbagai faktor lain. Mengutip pendapat Muhammad Tholhah Hasan, Darmadi menyatakan bahwa munculnya gerakan radikalisme -termasuk Islam radikal- di Indonesia terutama setelah datangnya era reformasi disebabkan variabel ajaran dan pemahaman, peranan media internet (IT), kondisi sosial domestik, dan konstalasi politik internasional. ${ }^{21}$

${ }^{21}$ Ahmad Darmadi, “Pondok Pesantren dan Deradikalisasi Islam Indonesia”, Jurnal Millah, Vol. XI, No. 1, Agustus 2011, h. 236.

Walisongo, Volume 23, Nomor 1, Mei 2015 
Berdasarkan laporan dan juga komunikasi yang dilakukan dengan para lulusan SMA Diponegoro yang kemudian melanjutkan studi ke berbagai perguruan tinggi, tidak sedikit di antara mereka yang berinteraksi dengan para aktivis Islam radikal. Para aktivis Islam radikal kebanyakan mendatangi mereka di tempat kos. Tujuan kedatangannya adalah untuk mengajak mereka bergabung. Mereka umumnya datang tidak hanya sekali atau dua kali, tetapi berkali-kali. Karakteristik aktivis Islam radikal memang sangat gigih dalam memegang ajaran agama yang diyakini dan berusaha sekuat tenaga untuk mengajak orang lain bergabung. ${ }^{22}$

Sistem rekrutmen anggota ini mirip dengan yang dilakukan oleh berbagai sekte agama di Barat. Semenjak tahun 1960-an, di Barat tumbuh berbagai sekte agama. Dalam merekrut anggota, mereka memanfaatkan "jaringan sosial yang sudah ada dan ikatan interpersonal." Secara lebih operasional, Dawson melukiskan sistem perekrutan ini dengan, "kawan merekrut kawan, anggota keluarga merekrut anggota keluarga lainnya, dan tetangga merekrut tetangga."23

Sejauh identifikasi yang dilakukan oleh pihak sekolah, tidak ada seorang pun alumni yang ikut bergabung ke dalam kelompok Islam radikal. Para alumni memang mengakui bahwa ajakan untuk bergabung datang bertubi-tubi. Semangat para aktivis Islam radikal memang sangat tinggi. Tetapi mereka tetap kukuh dan tidak tergoda. Pada titik ini, strategi pemberian pelajaran yang dilakukan selama tiga tahun menemukan relevansinya.

Pembelajaran Aswaja yang diberikan memang tidak hanya berkaitan dengan materi semata, tetapi juga dikontekstualisasikan dengan realitas perkembangan terkini. Guru pengajar Aswaja menerangkan bahwa tantangan yang kini dihadapi oleh umat Islam, khususnya penganut Aswaja, tidak ringan. Sekarang ini bermunculan berbagai kelompok, aliran, dan sekte yang sangat beragam. Keberadaan kelompok tersebut cukup menantang dan berbahaya karena mereka memiliki karakteristik eksklusif. Mereka yang masuk ke dalam kelompok semacam ini biasanya sulit untuk keluar.

Guru Aswaja seringkali memberikan gambaran tentang tantangan yang akan dihadapi jika para siswa kelak melanjutkan studinya. Berorganisasi saat kuliah merupakan salah satu wahana untuk meningkatkan kapasitas dan

\footnotetext{
22Wawancara dengan Mustofa, guru SMA Diponegoro Tulungagung, 20 Februari 2015.

${ }^{23}$ Lorne L. Dawson, "Who Joins New Religious Movements and Why: Twenty Years of Research and What have We Learned?," dalam Lorne L. Dawson (ed.), Cults and New Religious Movements: $a$ Reader, (USA, UKand Australia: Blackwell Publishing, 2003), h. 119.
} 
kualitas diri. Saat memilih organisasi diingatkan agar tidak memilih organisasi yang radikal. Jika ragu disarankan lebih baik untuk tidak ikut.

Penjelasan berulang-ulang dan penekanan terhadap signifikansi Aswaja dalam realitasnya cukup efektif untuk memberikan pemahaman kepada para siswa. Ketika mereka lulus dan melanjutkan studi, interaksi dengan kelompok yang dimaksudkan dalam pelajaran Aswaja baru menemukan bentuk yang sesungguhnya. Pada saat semacam itulah mereka berusaha keras menolak bergabung. Pelajaran Aswaja yang diberikan ternyata cukup efektif dalam membekali para siswa untuk tidak terlibat dalam gerakan Islam radikal. Para lulusan dalam realitasnya mampu membedakan antara organisasi yang radikal dan tidak.

Selain itu, strategi yang dilakukan adalah dengan membiasakan para siswa menjalankan ibadah sebagaimana amaliah Aswaja. Pada waktu yang telah dijadwalkan, para siswa dengan bimbingan guru menjalankan berbagai amaliah "Nahdliyyah" seperti istighāthah, dibā-an, mengadakan peringatan pada hari-hari besar Islam, ziarah kubur, dan juga tahlilan. Semua ibadah ini dilakukan secara terprogram. Semua siswa diwajibkan untuk mengikuti kegiatan pembiasaan tersebut. ${ }^{24}$

Strategi pembiasaan yang ditempuh SMA Diponegoro ini secara teoritis memiliki signifikansi dalam membangun karakter para siswa. Pembiasaan merupakan cara yang cukup efektif dalam menanamkan nilai-nilai dan moralitas ke dalam jiwa siswa. Nilai-nilai yang tertanam dalam dirinya ini akan termanifestasi dalam kehidupannya semenjak ia mulai melangkah ke usia dewasa. ${ }^{25}$

Pembiasaan ibadah yang rutin merupakan strategi yang penting untuk terus ditumbuhkembangkan. Para siswa akan memiliki kebiasaan ibadah secara baik. Perilaku mereka akan sesuai dengan norma dan tata nilai moral sebagaimana yang dijarakan agama. ${ }^{26}$ Mereka memiliki koridor perilaku yang baik. Kebiasaan yang terbangun tersebut dalam realitasnya telah menyatu dan menjadi bagian tidak terpisah dari kehidupan sehari-hari, baik saat masih duduk di SMA Diponegoro maupun jauh setelah mereka lulus.

Kehidupan pasca SMA membuat para siswa berhadapan dengan realitas yang dinamis. Pembelajaran Aswaja, termasuk melalui pembiasaan ibadah,

\footnotetext{
${ }^{24}$ Wawancara dengan Muhtarom, Selasa, 27 Januari 2015. 110.

${ }^{25}$ Armai Arief, Pengantar Ilmu dan Metodologi Pendidikan Islam, (Jakarta: Ciputat Press, 2002), h.

${ }^{26}$ Muhibbin Syah, Psikologi Pendidikan, (Bandung: Rosdakarya, 2000), h. 123.
} 
memberikan pengaruh nyata. Mereka tidak mudah terombang-ambing oleh tantangan yang ada. saat berinteraksi dengan kelompok lain, termasuk Islam radikal, mereka tetap memiliki penduan dalam menentukan sikap. ${ }^{27}$

Proses pembiasaan memang tidak selalu berjalan mulus. Pada saat awal dilakukan, tidak semua siswa bisa menikmatinya. Namun seiring perjalanan waktu, mereka menjadi terbiasa. Hal ini bermakna bahwa pembiasaan yang pada awalnya bersifat mekanis telah berubah menjadi bagian tidak terpisah dari kehidupan seharu-hari karena dilakukan secara terus-menerus. ${ }^{28}$

Pembelajaran Aswaja di SMA Diponegoro sesungguhnya juga memperkuat karakter para siswa. Mengutip pendapat Agus Wibowo, Hamiddin menyatakan bahwa dalam kerangka implementasi pendidikan karakter melalui nilai-nilai Aswaja, ada beberapa langkah yang bisa ditempuh. Pertama, keteladanan dari seluruh komponen sekolah, mulai dari pendidik, pimpinan, dan pemangku kebijakan di lembaga tersebut. Keteladanan ini penting karena para siswa dapat melihat secara langsung bagaimana aplikasi nilai-nilai Aswaja secara nyata dalam kehidupan sehari-hari.

Kedua, dilakukan secara konsisten dan terus-menerus. Hal ini mensyaratkan pelajaran Aswaja yang terintegrasi dan sistemtik. Pada proses penyampaiannya, selain aspek materi yang doktrinal, juga dilakukan kontekstualisasi agar Aswaja tidak menjadi pelajaran yang mengawang. Implementasinya dilakukan dengan proses pembiasaan (pembudayaan/ habituasi) nilai-nilai Aswaja dalam kehidupan nyata dimana semua komponen di lembaga pendidikan terlibat langsung. Proses habituasi ini tidak bisa berlangsung singkat dan sporadis. Dibutuhkan proses dan waktu yang lama sampai terinternalisasi ke dalam diri para siswa.

Ketiga, penanaman nilai-nilai karakter yang utama. Nilai-nilai karakter Aswaja adalah sikap tawassuț, tawāzun, ta'adul, dan tasāmuḥ. Nilai-nilai utama ini kemudian diintegrasikan dengan pendidikan karakter bangsa. Perangkat penanaman nilai-nilai karakter Aswaja tersebut juga harus disediakan dan direncanakan secara matang dan tepat sasaran sesuai kebutuhan.

Lebih lanjut Hamiddin menjelaskan bahwa selain tiga tahap sebagaimana yang ia usulkan, aspek yang tidak kalah penting adalah optimalisasi kaidah al-

27Wawancara dengan Koirudin, alumni SMA Diponegoro, Minggu, 22 Februari 2015.

${ }^{28}$ Hery Noer Ali, Ilmu Pendidikan Islam, (Jakarta: Logos Wacana Ilmu, 1999), h. 189. 
muhāfazah 'alā 'l-qadīm al-șāliḥ wa'l-akhdhu bi 'l-jadīd al-așlāh. Artinya bahwa nilai-nilai lama yang baik dijadikan pedoman atau landasan untuk mengimplementasikan nilai-nilai karakter Aswaja dalam konteks kekinian. Keteladanan, kontinuitas dan penanaman nilai-nilai karakter selalu direkonstruksi untuk menemukan model-model penanaman nilai-nilai karakter Aswaja yang aplikatif, humanis dan kontekstual. ${ }^{29}$

Para siswa juga dibekali dengan paham keagamaan yang diyakini kebenarannya. Paham keagamaan yang dimaksud adalah paham keagamaan yang secara khusus sesuai dengan apa yang dijalankan oleh ulama NU dan juga menjadi tradisi di dunia pesantren.

\section{F. Kesimpulan}

Semakin berkembangnya gerakan Islam radikal menjadi ancaman tersendiri bagi bangsa Indonesia yang kaya dengan keanekaragaman. Karena itulah harus dilakukan berbagai upaya untuk mencegah berkembangnya Islam radikal. Pendidikan merupakan media yang cukup strategis untuk menjalankan fungsi deradikalisasi. Pelajaran Aswaja yang diterapkan di SMA Diponegoro Tulungagung cukup strategis dalam menjalankan peran deradikalisasi. Aswaja mengandung beberapa nilai yang substansial, yaitu tawassut (moderat), taw $\bar{a}-$ zun (berimbang), dan tasāmuh (toleransi). Nilai-nilai ini merupakan modal penting untuk membangun pemahaman Islam yang tidak ekstrem.

Aswaja signifikan untuk direkonstruksi dan sosialisasikan kepada para siswa sebagai modal untuk pedoman kehidupan agama sehari-hari. Pedoman ini akan fungsional-aplikatif dan memberikan respons aktif-kreatif dalam berhadapan dengan realitas kehidupan sosial keagamaan yang semakin kompleks. Strategi pembelajaran Aswaja di SMA Diponegoro Tulungagung disusun dalam desain untuk memberikan pemahaman kepada para siswa. Selain melalui penyampaian materi secara klasikal, di sekolah itu juga dilakukan berbagai kegiatan untuk memperkokoh internalisasi Aswaja, seperti pembiasaan ibadah sehari-hari yang sesuai dengan ajaran Aswaja.[w]

\footnotetext{
${ }^{29}$ Hamiddin, "Nilai-nilai Aswaja dalam Pendidikan Karakter", dalam http://hamiddin.com/wpcontent/uploads/2014/03/Pendidikan-Karakter-Berbasis-Nilai-Nilai-Aswaja-Hamiddin.pdf, diakses pada tanggal 9 Maret 2015.
}

Walisongo, Volume 23, Nomor 1, Mei 2015 


\section{BIBLIOGRAFI}

Ali, A. Mukti, Alam Pikiran Islam Modern di India dan Pakistan, Bandung: Mizan, 1993.

Ali, Hery Noer, Ilmu Pendidikan Islam, Jakarta: Logos Wacana Ilmu, 1999.

Amin, M. Masyhur, NU dan Ijtihad Politik Kenegaraannya, Yogyakarta: Al-Amin Press, 1996.

Arief, Armai, Pengantar Ilmu dan Metodologi Pendidikan Islam, Jakarta: Ciputat Press, 2002.

Darmadi, Ahmad, "Pondok Pesantren dan Deradikalisasi Islam Indonesia", Jurnal Millah, Vol. XI, No. 1 Agustus 2011.

Dawson, Lorne L., "Who Joins New Religious Movements and Why: Twenty Years of Research and What have We Learned?", dalam Lorne L. Dawson (ed.), Cults and New Religious Movements: a Reader, USA, UK and Australia: Blackwell Publishing, 2003.

Departemen Pendidikan dan Kebudayaan, Kamus Besar Bahasa Indonesia, cet. III, Jakarta: Balai Pustaka, 1990.

Hakim, Abdul 'Dubbun', "Islam, Inklusivisme, dan Kosmopolitanisme", dalam Abdul Halim (ed.), Menembus Batas Tradisi Menuju Masa Depan yang Membebaskan, Refleksi atas Pemikiran Nurcholish Madjid, Jakarta: Kompas dan Universitas Paramadina, 2006.

Hakim, Lukman, Perlawanan Islam Kultural: Relasi Asosiatif Pertumbuhan Civil Society dan Doktrin Aswaja NU, Surabaya: Pustaka Eureka, 2004.

Hassan, Nik Mustapha Hj. Nik, "Civil Society for Sustainable Economic Development", dalam Syed Othman Alhabshi and Nik Mustapha Nik Hassan (eds.), Islam Knowledge and Ethics: a Partinent Culture for Managing Organizations, Kuala Lumpur: Institute of Islamic Understanding Malaysia (IKIM), 1998.

Kato, Hisanori, Kangen Indonesia, Indonesia di Mata Orang Jepang, cet. III, Jakarta: Kompas, 2013. 
Ma'arif, Ahmad Syafii, Islam dalam Bingkai Keindonesiaan dan Kemanusiaan: Sebuah Refleksi Sejarah, Bandung: Mizan bekerja sama dengan Ma'arif Institute Jakarta, 2009.

Madjid, Nurcholish, Islam, Doktrin dan Peradaban, Jakarta: Paramadina, 1992.

Mansyur, Wasid, Menegaskan Islam Indonesia, Belajar dari Tradisi Pesantren dan NU, Surabaya: Pustaka Idea, 2014.

Muchtar, Masyhudi, dkk., Aswaja an-Nahdliyah, Ajaran Ahlussunnah wa alJama'ah yang Berlaku di Lingkungan Nahdlatul Ulama, Surabaya: Khalista dan LTN NU Jawa Timur, 2007.

Muhaimin, "Urgensi Pendidikan Islam Multikultural untuk Menciptakan Toleransi dan Perdamaian di Indonesia", dalam Ali Maksum, Pluralisme dan Multikulturalisme Paradigma Baru Pendidikan Agama Islam di Indonesia, Yogyakarta: Aditya Media, 2011.

Muhammad, Hussein, "Memahami Sejarah Ahlus Sunnah Waljama'ah yang Toleran dan Anti Ekstrem", dalam Imam Baehaqi (ed.), Kontroversi Aswaja, Aula Perdebatan dan Reinterpretasi, Yogyakarta: LKiS, 2000.

Qodir, Zuly, Radikalisme Agama di Indonesia, Yogyakarta: Pustaka Pelajar, 2014.

Qomar, Mujamil, Menggagas Pendidikan Islam, Bandung: Remaja Rosdakarya, 2014.

Syah, Muhibbin, Psikologi Pendidikan, Bandung: Rosdakarya, 2000.

\section{Internet:}

Hamiddin, "Nilai-Nilai Aswaja dalam Pendidikan Karakter", dalam http:// hamiddin.com/wp-content/uploads/2014/03/Pendidikan-KarakterBerbasis-Nilai-Nilai-Aswaja-Hamiddin.pdf, diakses pada tanggal 9 Maret 2015.

\section{Wawancara:}

Khoirudin, Alumni SMA Diponegoro, 22 Februari 2015.

Walisongo, Volume 23, Nomor 1, Mei 2015 
Muhtarom, Kepala SMA Diponegoro dan guru Aswaja, tanggal 27 Januari 2015. Mustofa, Guru SMA Diponegoro Tulungagung, tanggal 20 Februari 2015. 